\title{
Robert Ciborowski
}

Uniwersytet w Białymstoku

e-mail: r.ciborowski@uwb.edu.pl

\section{KAPITAŁ JAKO CZYNNIK \\ POSTĘPU TECHNICZNEGO - WYBRANE ASPEKTY}

\section{CAPITAL AS A FACTOR \\ OF TECHNOLOGICAL CHANGE - SOME ISSUES}

DOI: $10.15611 / \mathrm{e} 21.2015 .3 .01$

JEL Classification: E22

Streszczenie: Modele akumulacji kapitału pokazują, że dobra kapitałowe mają jednakową produktywność, a za ich pomocą można wytwarzać dobra o podobnej jakości. Jednak w miarę postępu technicznego produktywność rośnie, a jakość dóbr będzie wyższa. Akumulacja kapitału determinuje postęp techniczny i odwrotnie - postęp techniczny tworzy gospodarcze możliwości akumulacji. Kapitał i stopień jego wykorzystania mają bezpośredni wpływ na możliwości technologiczne gospodarki, tworząc warunki do osiagania coraz wyższego poziomu rozwoju gospodarczego. W różnych okresach i podejściach ekonomicznych rola kapitału ewoluowała, ale zawsze stanowił on kluczowy czynnik wzrostu i rozwoju. Zmiany w jego strukturze i charakterze bezpośrednio decydują o skuteczności postępu technicznego, odzwierciedlanej w stopie zysku i poziomie oszczędności. A to z kolei wpływa na poziom akumulacji kapitału. Gospodarki o wysokim poziomie akumulacji mogą podążać ścieżką rozwoju opartą na innowacjach, pozostałe powinny stworzyć mechanizmy jego pozyskiwania. Jest to tym trudniejsze, że w wielu krajach kapitał jest niszczony inflacją i długiem publicznym, ograniczając branże produkujące dobra kapitałowe. Wykorzystanie procesów innowacyjnych w szerszym stopniu potrzebuje zasobów kapitałowych. Może się to dokonywać poprzez zmniejszanie ograniczeń i kosztów pozyskiwania i utrzymywania kapitału.

Słowa kluczowe: kapitał, postęp techniczny, akumulacja.

Summary: Models of accumulation show that capital goods have equal productivity and using them goods having similar quality can be produced. However, productivity increases together with technological change and the quality of goods gets higher. Capital accumulation influences technological change and technological change creates terms of new accumulation. Capital and the degree of its utilization have direct influence on technological capabilities of economy creating terms of faster economic development. The role of capital in different periods and economic approach evaluated but it was always a key factor of economic growth. Changes in the structure and character of capital directly decide about the efficiency of technological change reflected in the rate of profits and the level of savings, which influences the level of capital accumulation. High-level accumulation economies can pursue growth based on innovation, others have to find sources of capital gain. It is difficult because in a lot of countries a huge part of capital is wasted by inflation and public debt limiting sectors 
producing tangible goods. The use of innovation processes needs more widely capital resources. It may be accomplished through the reduction of constraints and the costs of raising and holding capital.

Keywords: capital, technological change, accumulation.

\section{Wstęp}

Na początku XXI wieku gospodarki wysoko rozwinięte doświadczają gruntownych zmian ekonomiczno-społecznych. Rewolucja techniczno-informatyczna tworzy nowe sektory oparte na biotechnologiach, mikroprocesorach i telekomunikacji, które powodują zmianę podejścia do zagadnienia postępu technicznego i produktywności. Fala innowacyjna spowodowała pojawienie się nowych relacji konsument-producent, nowych sposobów działania, kontroli jakości oraz tworzenia zespołów produkcyjnych. Aktywność gospodarcza coraz częściej przesuwana jest z sektora przemysłowego do usług. Gospodarki są w trakcie kolejnego z cyklów Schumpeterowskiej „twórczej destrukcji”.

Postęp techniczny stał się ,,iskrą" tego typu przemian, które przyspieszały jednocześnie z postępującą liberalizacją gospodarki światowej. Wraz ze spadkiem kosztów transportu i komunikacji, bardziej liberalnym handlem oraz likwidacją ograniczeń finansowych nastąpił wzrost przepływu dóbr, usług i kapitału między gospodarkami, który najsilniej odzwierciedlił się w przepływie bezpośrednich inwestycji zagranicznych (BIZ). Znaczna część gospodarek (głównie wysoko rozwiniętych) stała się bardziej otwarta, a większa konkurencja wymusiła wyższą ich innowacyjność. Proces ten w dużej mierze związany był z wykorzystaniem zasobów kapitałowych, powodując przyspieszenie rozwoju, ale również dynamiczne zmiany struktury gospodarczej.

Celem artykułu jest przegląd wybranych koncepcji roli kapitału jako czynnika zmian technologicznych oraz przebiegu procesów postępu technicznego w kontekście wzrostu gospodarczego. W tekście przedstawiono również konsekwencje ograniczeń kapitałowych i braku akumulacji.

\section{Postęp techniczny jako czynnik zmian produktywności}

Postęp techniczny, obok pracy, kapitału i dostępu do zagranicznych zasobów, uważany jest za jedną z najważniejszych sił napędowych wzrostu gospodarczego. Pozwala zajmować coraz lepsze miejsca w międzynarodowym podziale pracy, czerpać nadzwyczajne zyski z tytułu oferowania nowości na rynkach światowych. Stanowi istotę zmian we współczesnej, umiędzynarodowionej gospodarce. Przyjęcie szerokiego zakresu definicyjnego postępu technicznego pozwala na rozpatrywanie jego znaczenia pod kątem wprowadzania do gospodarki różnego rodzaju usprawnień dotyczących czynników produkcji. A. Smith ujmował czynniki produkcji w formie 
przepływów dochodów i wydatków (renty, płace, procenty) i przedstawiał jako wzajemne relacje produktywności wszystkich czynników. Wychodząc z założenia, że wartość jest konsekwencją pracy, Smith wyróżniał pracę produktywną i nieproduktywną. Praca produktywna rozumiana jako proces wynikała ze stopnia wyposażenia w kapitał, który powstaje dzięki oszczędzaniu. Postęp techniczny należało zatem traktować jako zmianę udziału kapitału i pracy w produkcji i ujmować w postaci tendencji do wzrostu kapitałochłonności, która z kolei związana jest z podziałem pracy i coraz lepszą specjalizacją [Smith 1904, s. 2].

„Trzem różnym okolicznościom zawdzięczamy, że ta sama liczba ludzi może w następstwie podziału pracy wykonać znacznie większą jej ilość: po pierwsze, wzrostowi sprawności każdego robotnika; po drugie, zaoszczędzeniu czasu, który się zwykle traci, gdy się przechodzi od jednego rodzaju pracy do drugiego; wreszcie, wynalezieniu wielkiej liczby maszyn, które ułatwiają i skracają pracę i pozwalają jednemu człowiekowi wykonywać pracę wielu ludzi” [Smith 1904, s. 20].

Zatem klasyczne podejście do postępu technicznego można przedstawić jako:

- lepsze wykorzystanie maszyn przez poszczególnych pracowników prowadzące do wyższej produktywności,

- $\quad$ specjalizację w produkcji maszynowej,

- pozyskiwanie wiedzy naukowej niezbędnej do lepszego wykorzystania kapitału.

Najistotniejszy z tych elementów, czyli specjalizacja, dotyczy pojawiania się nowych umiejętności czy szans, a nie uzyskiwania maksymalnych efektów produkcyjnych. Chodzi zatem o pewien proces nauczania czy pozyskiwania wiedzy w procesach wytwórczych. Smith dostrzegał rolę wiedzy i nauki w procesach poprawy produktywności, stąd jego koncepcja postępu technicznego.

Klasyczne podejście do postępu technicznego rozszerzył D. Ricardo, analizując możliwości substytucji pracy i kapitału w kontekście wpływu na poziom wiedzy technologicznej. Wzrost płac będzie prowadzić do wzrostu roli technologii oszczędzających pracę i zwiększających kapitałochłonność. W wieku XIX tendencja do podnoszenia płac był długotrwała, stąd coraz większe zainteresowanie technologiami kapitałochłonnymi. Proces ten musiał być zatem ściśle powiązany z akumulacją kapitału.

Inni ekonomiści klasyczni (Say, Ricardo) twierdzili, że w długim okresie rynek wykazuje zdolności do samoregulacji i kompensowania efektów zbyt długotrwałej tendencji do wykorzystywania technologii oszczędzających pracę poprzez [Tunzelmann, 1995, s. 20-26]:

1) nowe inwestycje, gdy zyski z wyższej produktywności są reinwestowane,

2) nowe maszyny - wzrost zatrudnienia w branżach produkujących nowe wyposażenie,

3) spadek płac - wzrost bezrobocia wymusi niższe wynagrodzenie,

4) niższe ceny - wyższa konsumpcja pobudzi zwiększenie produkcji,

5) nowe produkty - zatrudnienie w nowych branżach. 
Proces osiagania „stabilizacji technologicznej” może się odbywać jednak tylko w warunkach konkurencyjnych. W gospodarkach z dominującą rolą struktur monopolistycznych zjawisko to nie wystapi.

Postęp techniczny to nie tylko wykorzystanie technologii per se, ale przede wszystkim powiązanie wielu różnych aspektów działalności przedsiębiorstwa w celu wytworzenia określonego produktu. Jest to swego rodzaju konwersja wiedzy technologicznej w umiejętności stworzenia produktu oczekiwanego przez konsumentów. Zatem postęp techniczny może być utożsamiany z organizacją zdolności przedsiębiorczych w taki sposób, aby uzyskać możliwie najwyższą skuteczność rynkową. Produkt będący efektem tego procesu będzie się charakteryzować lepszym wykorzystaniem czynników produkcji (produktywność) oraz zwiększonym popytem (wyższe zyski ze sprzedaży) [Marshall 1930, s. 49-52].

Korzyści z postępu technicznego osiagną przedsiębiorstwa umiejętnie zarządzające: procesami wytwórczymi, finansowaniem, tworzeniem produktu i działalnością $\mathrm{B}+\mathrm{R}$. Powiązanie tych elementów w sposób możliwie najlepszy pozwoli na skuteczne wykorzystanie zasobów ludzkich i kapitałowych (wyższą produktywność).

Zatem w najszerszym ujęciu postęp techniczny oznacza nowe metody produkcji wytwarzanych już produktów, projekty nowych dóbr o innych cechach charakterystycznych, a także nowe techniki organizacji i zarządzania [Mansfield 1995, s. 473]. Wpływa on także na długookresową stopę wzrostu gospodarczego, likwidując działanie prawa malejących przychodów i decydując o zmianach relacji między produktem a poszczególnymi czynnikami produkcji. Poza tym postęp techniczny to „całość wiedzy społecznej wykorzystywanej w procesie wytwarzania, która rozdzielona pomiędzy zasoby ludzkie tworzy techniczne zasoby gospodarki oraz prowadzi do wyższej efektywności" [Schmookler 1966, s. 1]. Według Schmooklera zasoby techniczne zależą od stopy postępu technicznego i stopnia zastępowania starych rozwiązań, który wprost wynika z możliwości pozyskiwania kapitału.

Postęp techniczny powinien oznaczać przyjęcie metod dotychczas niewypróbowanych. Trzymając się definicji tradycyjnej, w wyniku wprowadzenia nowej metody produkcji koszt krańcowy będzie większy, ale jednocześnie wzrośnie poziom produkcji, spadną ceny i koszty przeciętne. W sferze procesu postęp techniczny, kluczowy z punktu widzenia wzrostu produktywności, był przedmiotem poważnej dyskusji od czasów Pigou, Schumpetera czy Wicksella. W latach 30. uwagę skupiał głównie problem sklasyfikowania go w grupach w pełni rozłącznych (pracooszczędny, kapitałooszczędny czy neutralny). Współczesna ekonomia skupia się bardziej na mechanizmie odpowiedzialnym za systematyczne ukierunkowanie nakładooszczędnej tendencji postępu technicznego.

Niektórzy ekonomiści eliminują z teorii postępu technicznego zmiany produktu. Traktowany jest wtedy jako wprowadzenie nowego procesu, który prowadzić będzie do redukcji przeciętnych kosztów produkcji niezmieniającego się w sposób istotny produktu [Rosenberg 1982, s. 4-5]. 
Według S. Kuznetsa nowe procesy ucieleśniają się we wprowadzaniu nowych maszyn lub urządzeń, które tworzą nowości z punktu widzenia firm je wytwarzających. Wysoka stopa wzrostu w gospodarkach uprzemysłowionych była odzwierciedleniem ciagłych zmian w produktach i procesach. Późniejsze obniżenie dynamiki wzrostu wynikało ze spadku oddziaływania postępu technicznego na redukcję kosztów przeciętnych, czyli mniejsze wykorzystanie zmian procesowych. Niskie w długim okresie dochody i cenowa elastyczność popytu dla starszych dóbr konsumpcyjnych dodatkowo zmniejszały możliwości spadku kosztów. Kontynuacja wzrostu wymagała więc rozwoju nowych produktów i nowych gałęzi przemysłowych opartych na większych inwestycjach kapitałowych [Kuznets 1930, s. 19-26]. Zmiany tego typu zdeterminowane były dostępnością kapitału, który stawał się ograniczony głównie w krajach rozwijających się. Symptomatyczny jest tu przykład Japonii w latach 70. XX wieku, która pozyskawszy wiedzę techniczną, potrzebowała jak największej ilości kapitału. Został on dostarczony przez kraje wysoko rozwinięte $\mathrm{w}$ postaci inwestycji kapitałowych oraz był konsekwencją rosnącego poziomu oszczędności wewnętrznych.

Ponadto gałęzie wykorzystujące postęp techniczny mogą uzyskiwać rosnące korzyści skali objawiające się wzrostem stopy inwestycji kapitałowych oraz przyspieszeniem procesu konwergencji. W znacznej mierze postęp techniczny jest indukowany inwestycjami kapitałowymi. Zależność tego typu przedstawia J.K. Arrow w modelu opartym na koncepcji „uczenia się przez działanie” (learning by doing). Endogenizuje on postęp techniczny w celu stworzenia warunków neoklasycznego wzrostu zrównoważonego i wprowadza elementy psychologii eksperymentalnej, która zakładała, że wszelkie uczenie się jest wynikiem doświadczenia będącego funkcją nie czasu, ale praktyki i działania [Arrow 1962, s. 159-162]. Arrow wysuwa hipotezę, że tempo postępu technicznego i bieżący poziom wiedzy są wynikiem doświadczenia produkcyjnego. Postęp techniczny ucieleśnia się w nowym wyposażeniu kapitałowym realizowanym z inwestycji i występuje w sektorze produkującym dobra kapitałowe, a także prowadzi do wzrostu wydajności pracy przez połączenie doświadczenia sektora kapitałowego i wydajności osób obsługujących nowe maszyny i urządzenia [Arrow 1962, s. 170].

Przedstawione podejście do postępu indukowanego opisuje, w jaki sposób realizowane są wydatki na B+R. Przedsiębiorstwa wybierają taką działalność, która charakteryzuje się inną intensywnością wykorzystywania czynników produkcji. Relatywne zmiany cen czynników sugerują, który nowy projekt może być zrealizowany według kryterium redukcji kosztów. Postęp techniczny optymalny z punktu widzenia cen czynników może się okazać niekorzystny z punktu widzenia innych warunków (np. wzrostu płac) [Uzawa 1965, s. 22] i może się ucieleśniać w poszczególnych czynnikach produkcji, głównie w kapitale ludzkim.

W teorii wzrostu endogenicznego można wskazać dwa podejścia do zależności między kapitałem ludzkim a wzrostem gospodarczym. Pierwsze z nich zaprezentował R. Lucas [1988, s. 3-42] inspirowany pracami G.S. Beckera, który kapitał ludzki 
traktuje tak jak inne czynniki produkcji, zakładając, że różnice w tempie wzrostu poszczególnych krajów zależą od stopy akumulacji kapitału ludzkiego. Podstawowe założenia tego podejścia nawiązują do tradycji klasycznej ekonomii, gdzie akumulacja jest czynnikiem wzrostu, a także do Schumpeterowskiej teorii innowacji, w której przedsiębiorczość jest główną determinantą rozwoju. W modelu technologia traktowana jest jako oddzielny, endogeniczny czynnik wyjaśniający wzrost produktywności w gospodarce. Drugie podejście reprezentują R. Nelson i E. Phelps [Nelson, Phelps 1966, s. 542-544], którzy wykorzystując Schumpeterowską teorię rozwoju gospodarczego, wskazują, że tempo wzrostu zależy od wielkości zasobu kapitału ludzkiego, który z kolei tworzy możliwości podnoszenia innowacyjności gospodarki i(lub) stwarza szanse na doganianie krajów lepiej rozwiniętych (catch-up). Różnice $\mathrm{w}$ tempie wzrostu gospodarczego w poszczególnych gospodarkach wynikają zatem $\mathrm{z}$ różnic $\mathrm{w}$ zasobie kapitału ludzkiego oraz w możliwościach generowania efektów postępu technicznego.

Postęp techniczny jest zatem zjawiskiem endogenicznym. Według nurtu neoklasycznego nieustanny wzrost gospodarczy jest możliwy przy występowaniu rosnących korzyści skali lub oddziaływaniu czynników zewnętrznych, które gwarantuja, że krańcowa produktywność akumulowanych czynników produkcji nie będzie dążyć do zera. Większość modeli przyjmuje ten specyficzny warunek akumulacji: określona wielkość zasobów produkcyjnych daje procentowy, ilościowy przyrost czynnika, nie zmieniając jego jakości [Silverberg, Soete 1994, s. 21]. Przykładem może być model P. Romera bez stałych przychodów, ale z ekonomią skali jako czynnikiem zewnętrznym, określający kapitał jako dobro niehomogeniczne i bardzo wewnętrznie zróżnicowane. Czynniki wytwórcze uzależnione są od wielkości wydatków na B+R [Romer 1990, s. 73].

W niektórych modelach endogenicznych problem przychodów skali został rozwiązany przez wykorzystanie funkcji produkcji, gdy praca jest częścią kapitału rzeczowego, a krańcowa produktywność kapitału jest stała. Jeżeli w modelu obok kapitału wystapiłyby czynniki nieakumulowane, dalszy wzrost gospodarczy wymagałby wystapienia rosnących korzyści skali [Rebelo 1991, s. 218]. Model Rebelo nie podnosi jednak ważności postępu technicznego, dopiero Romer wprowadza do rozważań pojęcia innowacji, inwencji czy dyfuzji. Według Romera endogeniczny model postępu technicznego opiera się na czterech czynnikach: kapitale, pracy, kapitale ludzkim i technice wyznaczanej przez wskaźnik poziomu innowacyjności. Kapitał mierzony jest jednostkami trwałych dóbr konsumpcyjnych aktualnie wykorzystywanych w produkcji, praca - liczbą zdrowych fizycznie osób dostępnych na rynku, kapitał ludzki - liczbą skumulowanych efektów działań ludzkich, takich jak nauka, dokształcanie czy staże zawodowe (tak zdefiniowany jest czynnikiem nieograniczonym). Poziom innowacyjności określa poziom wydatków na $\mathrm{B}+\mathrm{R}$ oraz przychody z patentów [Romer 1990, s. 79]. W modelu Romera postęp techniczny jest wynikiem nie akumulacji, lecz specyficznego rodzaju aktywności badawczo-rozwojowej (B+R) wynikającej z indywidualnych decyzji ludzi [Romer 1986, s. 88]. 
Postęp techniczny utożsamiany z powiększaniem wiedzy w przedsiębiorstwach jest tworzony za pomoca kapitału ludzkiego z wykorzystaniem zakumulowanej w poprzednim okresie wiedzy. Jest ona przenoszona od twórców (kapitał ludzki) do działu bezpośrednio produkującego (praca). Im więcej pracowników znajduje się w dziale produkcyjnym, tym więcej kapitału ludzkiego potrzeba do transferu wiedzy. Wzrost zasobu wiedzy będzie więc odwrotnie proporcjonalny do liczby pracowników w sferze produkcyjnej [Ziesemer 1993, s. 9].

\section{Czynniki określające wykorzystanie kapitału w procesie postępu technicznego}

G.M. Grossman i E. Helpman, wykorzystując funkcję produkcji Cobba-Douglasa, określili warunki wykorzystania dóbr pośrednich w produkcji, które ucieleśniają wiedzę techniczną i powiększane są inwestycjami technologicznymi [Grossman, Helpman 1990, s. 124-126]. Przedstawili relacje między wzrostem kapitału i produkcji w sposób charakterystyczny dla neoklasycznych modeli wzrostu. Wzrost gospodarczy jest proporcjonalny do stopy wzrostu TFP (total factor productivity), która wynika $\mathrm{z}$ kolei $\mathrm{z}$ tempa postępu technicznego. Wzrost wiedzy następuje, gdy więcej pracy jest alokowanej w badaniach, natomiast alokacja zasobów wynika z zasady maksymalizacji zysku.

Model Grossmana-Helpmana pozwala umieścić więcej zasobów w procesie innowacyjnym, który zależy od różnorodnych czynników: rozmiarów rynku, wydajności pracy badawczej i stopnia siły rynkowej w sprzedaży produktów będących rezultatem postępu technicznego. Polityka gospodarcza może oddziaływać na długookresową stopę wzrostu przez decyzje dotyczące określenia wielkości zasobów alokowanych w sektorze innowacyjnym, różnicując przy tym istotę postępu technicznego na kreację i dyfuzję. Wzrost gospodarczy może wynikać np. z liberalizacji handlu zagranicznego, polityki wspierającej konkurencję, relatywnego wzrostu atrakcyjności badań dla ludzi utalentowanych, co rząd jest w stanie wspierać przez subsydiowanie inwestycji w B+R czy modyfikację prawa patentowego. Głównym problemem w tym wypadku jest możliwość zwrotu kosztów innowacji.

Współczesne neoklasyczne modele wzrostu opierają się na założeniu występowania nieskończonej liczby procesów produkcyjnych, które bez przeszkód przechodzą jeden w drugi. Rezultatem tego jest ciagłość zmian relacji produkt-kapitał. Stopa wzrostu kapitału nie jest szczegółowo określona, ale wynika z decyzji inwestycyjnych przedsiębiorstw oraz skłonności do oszczędzania.

Jeśli przyjmiemy założenie o zmienności kapitałowej intensywności pracy, funkcja produkcji zostanie określona jako:

$$
Y=F(K, L) \text { dla: } K, L>0,
$$

gdzie: $Y$ - produkt, $K$ - kapitał, $L$ - praca.

Funkcja jest zagregowana w sensie makroekonomicznym. 
Przyjmując występowanie funkcji (1) oraz zmiany relacji czynników produkcji, można zapisać:

$$
Y=L F\left(\frac{K}{L}, 1\right)=L \eta(k), \text { gdzie: } k \equiv \frac{K}{L} .
$$

Nowa funkcja $h$, która zgodnie z twierdzeniem Eulera daje przeciętny produkt pracy dla każdej proporcji kapitału i pracy, rośnie wraz ze wzrostem $k$, ale w coraz wolniejszym tempie. Z kolei produktywność krańcowa kapitału wyniesie:

$$
F_{K} \equiv \frac{\sigma Y}{\sigma K}=\eta^{\prime}(k) \text {. }
$$

Jeżeli $F_{K}>0$, to $\eta^{\prime}(k)>0$. Przy założeniu o równości inwestycji i oszczędności $(I=S)$ oraz że oszczędności są stałą częścią produktu $(S=s Y)$, a także zależność produkcji od nakładów kapitału i pracy, względna zmiana kapitału:

$$
K^{\prime}\left(\equiv \frac{d K}{d t}\right)=s Y-\lambda K
$$

gdzie $s$ - krańcowa skłonność do oszczędzania, $l$ - stopa deprecjacji kapitału.

Zależność ta pokazuje, że stała część produktu jest inwestowana ${ }^{1}$. Racjonalne postępowanie podmiotów gospodarczych daje możliwość ustalenia stopy oszczędności przez porównanie kosztów i zysków z teraźniejszej konsumpcji. Relacja ta pozwala wprowadzić parametry i zmienne opisujące stan gospodarki.

Zasoby siły roboczej rosną wykładniczo w stałym tempie:

$$
\frac{L^{\prime}}{L}\left(\equiv \frac{d L / d t}{L}\right)=\psi, \text { dla }(\psi>0),
$$

gdzie $\psi-$ stopa wzrostu siły roboczej.

Przyjmując powyższe założenia, można zapisać prostą pojedynczą zależność względem jednej zmiennej. Wykorzystując równania (2) i (4), otrzymamy:

$$
K^{\prime}=s L \eta(k)-\lambda K \text {. }
$$

Ponieważ $k \equiv \frac{K}{L}$ i $K \equiv k L$, to różniczkując ostatnią tożsamość, otrzymamy:

$$
K^{\prime}=k^{\prime} L+k L^{\prime}=k^{\prime} L+k \psi L
$$

${ }^{1} \mathrm{~W}$ neoklasycznych modelach wzrostu następuje pełne wykorzystanie czynników produkcji, wtórny w stosunku do oszczędności charakter inwestycji oraz szeroki zakres substytucji, zarówno ex post, jak i ex ante, między pracą i kapitałem. 
Porównując (4) do (6) i biorąc pod uwagę (2):

$$
k^{\prime}=s \eta(k)-\psi k-\frac{\lambda K}{L} .
$$

oraz likwidując czynnik $(L)$, otrzymamy:

$$
k^{\prime}=s \eta(k)-(\lambda+\psi) k
$$

Jest to centralne równanie modelu Solowa-Swana, nieliniowe i zależne jedynie od $(k)$. Warunek $(\lambda+\psi)$ może być opisywany jako efektywna stopa deprecjacji dla relacji kapitał/praca $\left(k \equiv \frac{K}{L}\right)$. Jeżeli względna zmiana $k$ 'wyniesie: $\frac{k^{\prime}}{k}=s \frac{\eta(k)}{k}-(\lambda+\psi)$, to dla: $s, \lambda, \psi=$ constans. Wynika stąd, że $\frac{\eta(k)}{k}=$ constans oraz $\frac{F(K / L ; 1)}{K / L}=\frac{F(K, L)}{K}=$ constans, gdy stopa wzrostu kapitału i pracy są takie same. Wówczas $k=$ constans oraz $k^{\prime}=0$. Jeżeli stopa oszczędności wyniesie 0 , wtedy $k$ powinno się zmniejszyć, częściowo z powodu amortyzacji $K$ (według stopy $l$ ) oraz wzrostu $L$ (według stopy $\psi$ ).

Funkcja inwestycji jest proporcjonalna do funkcji produktu. Konsumpcja jest różnicą między tymi wielkościami. Zmiany $(k)$ wyznaczane są różnicą odległości między funkcją inwestycji a krzywą deprecjacji. W stanie steady state stopy wzrostu produktu, konsumpcji i kapitału są równe stopie wzrostu nakładów pracy, a zatem stopie powiększania się liczby ludności.

Stan wzrostu zrównoważonego dla funkcji (8) jest wtedy, gdy $k=0$ (czyli $k=$ constans). W punkcie $k_{S}$ funkcja będzie miała postać:

$$
s \eta\left(k_{S}\right)=(\lambda+\psi) k_{S} .
$$

Jeżeli relacja kapitału do pracy jest stała, to wydajność pracy i konsumpcja per capita także będą stałe i wyniosą: $y_{S}=\eta\left(k_{S}\right)$ oraz $c_{S}=(1-s) \eta\left(k_{S}\right)$. Stałość wielkości per capita oznacza, że kapitał, produkt i konsumpcja rosną według stopy wzrostu ludności $(y)$.

Zmiany w poziomie techniki określane będą przesunięciem funkcji produkcji $\eta\left(k_{S}\right)$ dla stopy oszczędności. Podobnie będzie w przypadku stopy wzrostu ludności i stopy amortyzacji kapitału. Wszystkie zmiany dotyczyć będą stanu wzrostu zrównoważonego i wielkości per capita [Grossman, Helpman 1991, s. 24-25].

Zmiany kapitału i konsumpcji per capita w stanie wzrostu zrównoważonego wynoszą 0 , a co za tym idzie, zmiany techniczne, stopy oszczędności, stopy wzrostu ludności czy amortyzacji kapitału nie wpływają na wzrost produktu. Model nie wyjaśnia więc długookresowego wzrostu produktu per capita [Solow 1967, s. 20-23]. 
Przyjmując stan wzrostu zrównoważonego i wykorzystując równanie (5), możemy zapisać wielkość konsumpcji:

$$
c_{S}(s)=\eta\left[k_{S}(s)\right]-(\lambda+\psi) k_{S}(s)
$$

oraz po zróżniczkowaniu po (s) warunku równowagi (steady state):

$$
\eta\left(k_{S}\right)+s \eta\left(k_{S}\right) \frac{d k_{S}}{d s}=(\lambda+\psi) \frac{d k_{S}}{d s}
$$

i dalej:

$$
\eta\left(k_{S}\right)=\frac{d k_{S}}{d s}\left[\lambda+\psi-s \eta^{\prime}\left(k_{S}\right)\right],
$$

przy założeniu, że: $k_{S}>0 \Rightarrow \eta\left(k_{S}\right)>0$

oraz:

$$
\frac{d c_{S}}{d s}=\left[\eta^{\prime}\left(k_{S}\right)-(\lambda+\psi)\right] \frac{\eta\left(k_{S}\right)}{\lambda+\psi-s \eta^{\prime}\left(k_{S}\right)} .
$$

Wielkość $c_{S}$ jest rosnąca przy niskiej stopie oszczędności i malejąca przy wysokiej. Konsumpcja dla stanu wzrostu zrównoważonego będzie maksymalna, gdy:

$$
\left[\eta^{\prime}\left(k_{S}\right)-(\lambda+\psi)\right] \frac{d k_{S}}{d s}=0 .
$$

Biorąc pod uwagę poprzednie założenia, można wnioskować, że wyrażenie w nawiasach musi być równe 0 . Przyjmując wartość $k_{O P T}$ dla stanu wzrostu zrównoważonego jako optymalną dla maksymalnego poziomu $c_{S}$, otrzymujemy

$$
\eta^{\prime}\left(k_{O P T}\right)=\lambda+\psi \text {. }
$$

Stopa wzrostu oszczędności będzie zapisana jako $\left(s_{O P T}\right)$, a konsumpcja per capita w stanie wzrostu zrównoważonego:

$$
c_{O P T}=\eta\left(k_{O P T}\right)-(\lambda+\psi) k_{O P T} .
$$

Dla powyższego równania można określić zlotą regułę akumulacji kapitału Phelpsa, która mówi, że ,jeżeli wszystkim uczestnikom gospodarki dostarczana będzie taka sama ilość konsumpcji obecnie i w przyszłości, to maksymalny poziom konsumpcji per capita wyniesie $c_{O P T}$ " [Phelps 1966, s. 139-141].

Istotą postępu technicznego będzie utrzymanie wielkości produktu przy relatywnie mniejszym wykorzystaniu czynników produkcji. Możemy więc określić postęp techniczny jako oszczędzający pracę i oszczędzający kapitał. Jeżeli relacja nakładów się nie zmieni, postęp techniczny będzie neutralny.

Nieucieleśniony postęp techniczny łączył zmiany produktywności z całkowitymi zasobami kapitału i pracy lub obu tych czynników jednocześnie (homogeniczność czynników produkcji), co odpowiadało założeniom o nieograniczonej substy- 
tucji pracy i kapitału (zarówno ex post, jak i ex ante). Jest to charakterystyczne dla neoklasycznej teorii wzrostu, w przeciwieństwie do ekonomii postkeynesowskiej, zakładającej niezmienność relacji kapitał/praca.

Rozwinięcie teorii TFP przez Parente i Prescotta [Parente, Prescott 2000, s. 54] pozwoliło na uwzględnienie specyfiki polityki gospodarczej prowadzonej $\mathrm{w}$ poszczególnych krajach. Ich podejście można nazwać „teorią relatywnej efektywności”, ponieważ dekomponują oni krajowe TFP na dwa składniki:

- czysta wiedza lub technika (A),

- efektywność (E).

Uwzględniając kontekst Hansena i Prescotta [Hansen, Prescott 2002, s. 1207-1209], funkcję wzrostu produkcji można przedstawić następująco:

$$
Y_{S t}=E_{S} A_{S t} K_{S t}^{\alpha} L_{S t}^{1-\alpha} .
$$

Składnik technologiczny TFP jest wspólny dla poszczególnych krajów, gdyż produktywność zasobu dostępnej wiedzy jest również taka sama. Efektywność z kolei jest inna i wynika ze zróżnicowania polityki ekonomicznej i układu instytucjonalnego. Zasadniczymi elementami są różny charakter polityki fiskalnej i pieniężnej, stopień otwartości gospodarki, rynek pracy, polityka innowacyjna i konkurencyjność oraz sprawność systemu prawnego. Poziom efektywności poniżej jednego pokazuje, że analizowana gospodarka osiaga poziom produkcji niższy od potencjalnego, czyli znajduje się poniżej krzywej możliwości produkcyjnych, zatem implikuje różnice $\mathrm{w}$ poziomie TFP.

Model Parente-Prescotta może służyć do wyjaśnienia procesu konwergencji w poszczególnych gospodarkach oraz istoty jej dynamiki w relatywnie krótkim czasie. Takie kraje, jak Botswana, Chiny, Japonia, Korea Południowa czy Tajwan, były zdolne do podwojenia swoich standardów życiowych po II wojnie światowej w okresie krótszym niż dekada. Dotyczyło to jednak krajów słabo rozwiniętych. Przyczyną tak wysokiej dynamiki procesów rozwojowych był relatywny wzrost efektywności oraz transformacja systemów gospodarczych w stronę większej otwartości.

Różnice w sposobie i intensywności przepływu postępu technicznego związane są również z rodzajem funkcjonującego systemu gospodarczego. Biorąc pod uwagę system liberalny i etatystyczny, można wskazać wiele czynników, które przez swoją specyfikę uwidaczniają różnorodność dyfuzji postępu technicznego. Najważniejsze aspekty decydujące o sprawności systemu w procesie adaptacji postępu technicznego to: system pieniężny i fiskalny gospodarki, rynek pracy, rynek technologii, struktura gospodarki, stopień otwartości oraz układ instytucjonalny.

\section{Preferencja czasowa i jej wpływ na postęp techniczny}

Rolę kapitału w procesach rozwoju technologicznego przedstawili w sposób całościowy ekonomiści szkoły austriackiej, opierając swoje podejście na teorii kapitału oraz pojęciu preferencji czasowej. Każde ludzkie działanie zawiera kategorię prefe- 
rencji czasowej [Mises 2007, s. 411]. Działający człowiek kieruje się chęcią uzyskania satysfakcji (korzyści) z realizacji potrzeb w przyszłości. Oczywiste jest, że zawsze będzie chciał osiagnąć swoje cele w bliższej niż w dalszej przyszłości. Realizacja każdego zamierzenia z uwzględnieniem preferencji czasowej ma swoje konsekwencje w długości etapów produkcji i konsumpcji.

W zmiennej gospodarce co jakiś czas pojawiają się konieczności wyboru między sposobami zaspokajania potrzeb w różnych okresach. Biorąc pod uwagę oczekiwane korzyści, podmioty gospodarcze mogą decydować, czy przeznaczać swoje dochody na konsumpcję czy akumulację, realizować swoje oczekiwania w okresie teraźniejszym czy też przenieść je w przyszłość. Decyzje te podejmowane są na podstawie oceny efektów uzyskiwanych w kolejnych okresach, z uwzględnieniem satysfakcji możliwej do osiagnięcia.

Według Misesa teoremat preferencji czasowej wskazuje na dwa przypadki [Mises 2007, s. 412]:

1. Sytuacja oszczędzania, gdy podmioty wybierają między natychmiastową konsumpcją pewnej ilości dóbr a późniejszą konsumpcją tej samej ilości dóbr.

2. Oszczędzanie kapitalistyczne, czyli wybór między obecną konsumpcją dóbr a późniejszą konsumpcją ich większej ilości lub późniejszą konsumpcją dóbr dających wyższą satysfakcję.

Działający podmiot dąży zatem do stanu bardziej zadowalającego, przedkłada dobra wytworzone wcześniej nad późniejsze oraz dobra bardziej trwałe nad mniej trwałe.

Preferencja czasowa jest powiązana z wykorzystaniem kapitału inwestycyjnego [Jevons 1888, rozdz. 7]. Tworzenie nowych, bardziej efektywnych metod produkcji wymaga inwestowania, czyli wcześniejszych oszczędności. Ilość oszczędności i inwestycji jest ograniczona preferencją czasową [Mises 2007, s. 483]. Musi zatem istnieć dodatnia stopa preferencji czasowej, aby niektóre podmioty miały skłonność do oszczędzania. Stopa preferencji czasowej wyznacza wielkość premii, którą dobra teraźniejsze mają w stosunku do dóbr przyszłych, a tym samym decyduje o poziomie inwestycji i oszczędności [Hoppe 2006, s. 33].

Oszczędności pozwalają na wymianę dóbr konsumpcyjnych (teraźniejszych) na dobra kapitałowe (przyszłe). Premia za takie postępowanie oraz oczekiwanie większej liczby dóbr konsumpcyjnych w przyszłości prowadzą do spadku stopy preferencji czasowej i zwiększenia oszczędności i inwestycji. Oczekiwania coraz wyższych dochodów realnych powodują, że stopa preferencji czasowej będzie spadać, a krańcowa użyteczność przyszłego pieniądza staje się coraz wyższa [Hoppe 2006, s. 36]. Implikuje to, że ludzie skłonni są podejmować decyzje, których efekty obserwowalne będą w coraz dalszej przyszłości. Co więcej, decyzje inwestycyjne będą dotyczyły bardziej skomplikowanych procesów produkcyjnych.

Dzięki niższej preferencji czasowej i dążeniu do realizacji coraz bardziej skomplikowanych procesów pojawia się zainteresowanie nową wiedzą, informacją oraz możliwościami skorzystania z bardziej skomplikowanych procesów wytwórczych. 
Chęć realizacji nowych idei, opartych czasami na nieznanych jeszcze rozwiązaniach, stwarza warunki postępowi technicznemu. Skłonność do ponoszenia większego ryzyka, które jest immanentną częścią postępu technicznego, wynika zatem z preferencji czasowej i w bezpośredni sposób o niej decyduje. Skuteczność procesów technologicznych pozwala na większe zainteresowanie się możliwościami inwestycyjnymi, czyli wyższą skłonnością do oszczędzania.

Preferencja czasowa ma jeszcze jedną cechę, a mianowicie jest konsekwencją skłonności do ryzyka i odzwierciedla rzeczywiste reakcje ludzi przy podejmowaniu decyzji inwestycyjnych. Tym samym jest to skuteczniejszy proces podnoszenia poziomu rozwoju technologicznego niż jakiekolwiek czynniki egzogeniczne (interwencjonistyczne). Ma to związek ze zmniejszeniem ryzyka i odpowiedzialnością za osiagane cele, co przy interwencji nie wystapi. A mianowicie, skłonność do oszczędzania nie wzrośnie (preferencja nie spadnie) i ograniczona zostanie rzeczywista ocena skutków. Tak długo, póki interwencja (we własność lub proces produkcji) nie występuje, utrzymywać się będzie spadkowa tendencja stopy preferencji czasowej i związany z nią postęp techniczny.

Konsekwencje interwencji w preferencję czasową w aspekcie postępu technicznego będą zatem następujące: niebezpieczeństwo przejęcia efektów postępu przez podmiot interweniujący, zmiana charakteru czy przebiegu procesów wytwórczych oraz ograniczenie roli ryzyka w podejmowaniu decyzji produkcyjnych (przeniesienie części lub całości ryzyka na interweniującego).

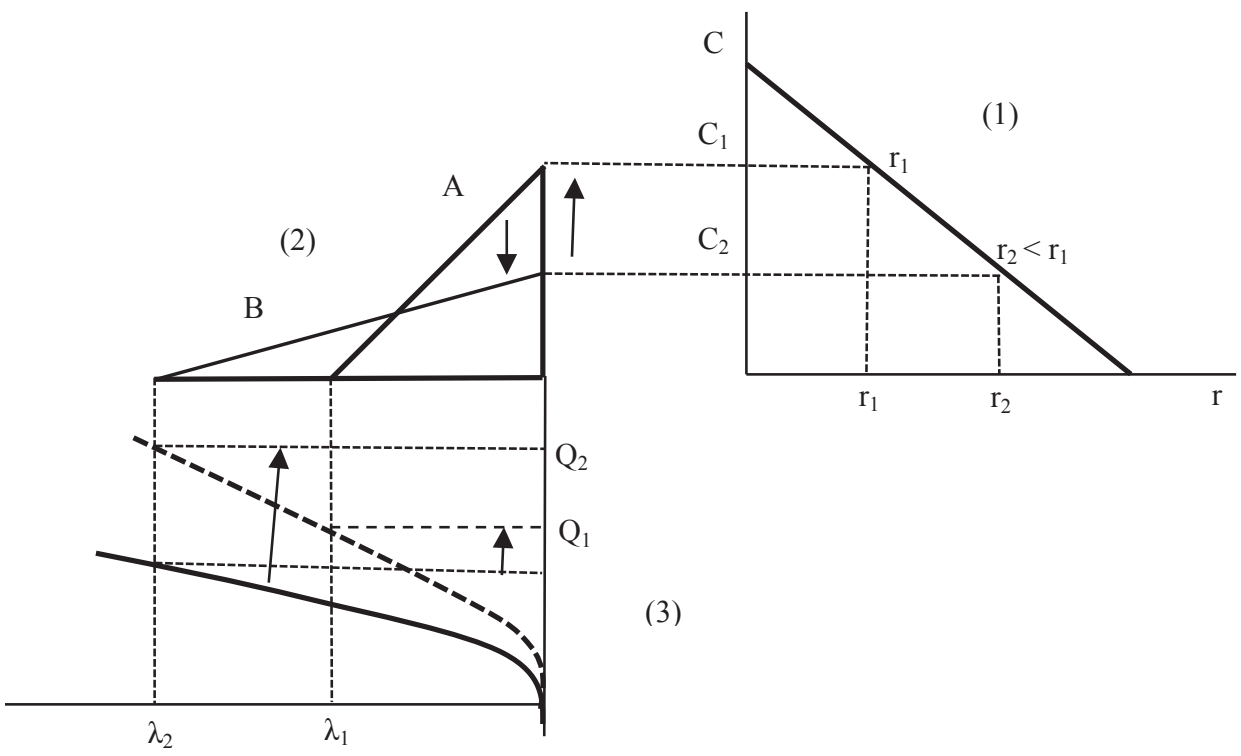

Rys. 1. Postęp techniczny w modelu values-riches

Źródło: opracowanie własne na podstawie: [Fillieule 2005, s. 3-19]. 
Rolę i zakres oddziaływania preferencji czasowej na postęp techniczny można przedstawić za pomocą modelu values-riches [Fillieule 2005, s. 3-19]. Pozwala on na jednoczesne ujęcie realnych i nominalnych zmiennych oraz na wskazanie prawidłowych zależności występujących między nimi. Poszczególne części wykresu (zob. rys. 1) ukazują wzajemne relacje makroekonomiczne występujące w warunkach równowagi: konsumpcji (C), inwestycji (I), produkcji dóbr konsumpcyjnych (Q) i stopy procentowej (r).

W części pierwszej (1) zaprezentowano linię zagregowanych wydatków pieniężnych w równowadze (values). Część druga (2) to etapy produkcji odzwierciedlające zmienne pieniężne i wskazujące na długość procesów produkcyjnych. Etapy produkcji w zależności od wysokości stopy procentowej (r) mogą się wydłużać lub skracać (A, B), co odzwierciedla makroekonomiczna funkcja produkcji w części trzeciej. Część trzecia (3) pokazuje zależność między długością etapów produkcji (1) a funkcją produkcji odzwierciedlającą ilość wyprodukowanych w ciagu roku dóbr konsumpcyjnych (riches).

Głównymi czynnikami wzrostu gospodarczego są: mniejsza preferencja czasowa (rosną inwestycje), postęp techniczny i wzrost zasobów pracy. Przy założeniu, że zasoby pracy są względnie stałe, a preferencja czasowa nie jest przedmiotem rozważań, pokazany zostanie jedynie wpływ postępu technicznego na wielkość produkcji.

Postęp techniczny jest reprezentowany przez zmianę położenia funkcji produkcji i wzrost rocznego poziomu wytwarzania dóbr i usług dla określonej długości etapów produkcji (przy zmianie preferencji czasowej). Ze względu na to, że postęp techniczny zwiększa średni poziom dochodów, preferencja czasowa również powinna się zmienić. W przypadku „neutralnego” postępu technicznego stopa procentowa i relacja $C / I$ nie ulegają zmianie.

W przypadku postępu technicznego „sprzyjającego" inwestycjom dzięki wzrostowi dochodów rośnie stopa oszczędności podmiotów gospodarczych i następuje wzrost inwestycji. Podmioty gospodarcze mają niższą preferencję czasową (wydłużają się etapy produkcji), co prowadzi do niższej stopy procentowej i spadku relacji C/I. Wzrost gospodarczy wynikać zatem będzie z dwóch źródeł: postępu technicznego i niższej preferencji czasowej. Mechanizm ten związany jest z podejściem endogenicznym do wzrostu, w którym czynniki wewnętrzne same wywołują kolejne fazy wzrostu. Niska preferencja czasowa powoduje, że w kolejnych etapach może być ona jeszcze niższa, oddziałując na wyższe inwestycje i wzrost gospodarczy. Oczywiście taki proces nie może być trwały, co wynika z założenia, że kolejne spadki preferencji są konsekwencją rosnącej produkcji i dochodów. Nie zawsze taką tendencję udaje się utrzymać w długim okresie.

W przypadku postępu technicznego „sprzyjającego” konsumpcji sytuacja jest odwrotna. Konsumenci stają się zamożniejsi dzięki postępowi technicznemu i decydują się więcej wydawać na konsumpcję (rośnie preferencja czasowa). Etapy produkcji stają się krótsze i w efekcie rosną stopy procentowe i relacja C/I. Wzrost go- 
spodarczy nie jest tak wysoki i stabilny jak przy postępie inwestycyjnym. Poza tym ma charakter krótkotrwały i jest silnie uzależniony od nastrojów konsumenckich.

Tego typu postęp techniczny bardzo często dokonuje się przy interwencji państwa opartej na finansowaniu z długu. Charakteryzuje się raczej wprowadzaniem ulepszeń, a nie radykalnie nowych rozwiązań produkcyjnych (rosnąca skłonność konsumentów do posiadania coraz większej ilości dóbr) oraz jest konsekwencją rosnących wydatków konsumenckich (związanych z interwencją). Przedsiębiorstwa nie poszukują zmian skierowanych na obniżkę kosztów (procesowych), gdyż interwencja zapewnia ciągły dopływ środków pieniężnych. Długookresową konsekwencją tego typu procesów będzie cykliczność zmian technologicznych oraz zwiększenie przyszłych obciążeń konsumenckich, co z kolei podniesie preferencję czasową i obniży skłonność do inwestowania.

Przekształcanie dóbr wyższego rzędu w dobra niższego rzędu tworzy pewien związek przyczynowości, który z kolei łączy się z czasem. Upływ czasu między kolejnymi fazami procesu przekształcania dóbr powinien być coraz krótszy. Świadczy to o rozwoju środków produkcji, ale przede wszystkim o postępie technicznym. Oczywiście nigdy nie dojdzie do sytuacji, w której czas przestanie mieć znaczenie, jednak cykl przekształceń dóbr powinien być coraz krótszy. Dobra wyższego rzędu uzyskują swój charakter nie dzięki potrzebom istniejącym w teraźniejszości, lecz z powodu przyszłych potrzeb, które pojawią się po zakończeniu cyklu produkcyjnego, a których wystapienie można przewidzieć [Menger 2014, s. 68-69].

Stopień trafności przewidywań co do przyszłej jakości i ilości produktu zależy od poziomu wiedzy dotyczącej elementów łańcucha przyczynowego wykorzystanych $\mathrm{w}$ procesie produkcji oraz od stopnia kontroli nad tymi elementami. Jest to związane z niepewnością, która determinuje relacje jakościowo-ilościowe. Będzie ona tym większa, im bardziej wzrośnie ilość elementów związanych z produkcja, których nie można zrozumieć lub kontrolować [Menger 2014, s. 71].

Zaspokojenie potrzeb staje się zatem procesem dążenia do zagwarantowania realizacji przyszłych oczekiwań, czyli dostępności takiej ilości i jakości dóbr, która jest wystarczająca do tego zaspokojenia w określonym przez konsumenta czasie. Aby to zrealizować, potrzebne jest posiadanie określonej wiedzy. Według Mengera konieczna jest znajomość [Menger 2014, s. 79]:

- oczekiwań danej jednostki, to znaczy ilości koniecznych do zaspokojenia potrzeb, dóbr w okresie objętym jej planem,

- ilości posiadanych przez nią dóbr zdolnych do spełnienia tych oczekiwań.

Brak pierwszego rodzaju wiedzy skutkowałby prowadzeniem działalności „na ślepo", ponieważ nieznany byłby cel w postaci rodzaju i ilości zaspokajanych potrzeb. Przy braku drugiego rodzaju nieznane byłyby środki, za pomocą których cel mógłby zostać osiagnięty.

Poszczególne rodzaje wiedzy wykorzystywać będą podmioty, które posiadają kontrolę nad środkami, określając, jakim celom mają one służyć. Innymi słowy jakie wartości należy cenić bardziej, a jakie mniej. Dlatego też tylko jednostki mogą 
samodzielnie realizować plan zaspokajania potrzeb, gdyż tylko one są w stanie prawidłowo ocenić, ile i jakiego rodzaju dóbr potrzebują [Hayek 2003, s. 76]. Postęp techniczny wynika zatem z działań jednostek i braku ograniczeń w ich planach oraz wolnej konkurencji, która nie pozwoli na powstawanie monopoli technologicznych.

$\mathrm{W}$ obecnych warunkach etatystycznej gospodarki procesy technologiczne moga same powodować nieuchronność rozrostu monopoli. Z kolei gospodarka liberalna gwarantuje wolność, czyli taki stan społeczny, którego całokształtu nie obejmuje żaden system instytucjonalno-prawny. Obok wielu różnych rodzajów wolności niezmiernie ważna jest w niej wolność ekonomiczna [Godłów-Legiędź 1992, s. 46]. W jej warunkach postęp techniczny jest procesem, w którym jednostki dążą do osiagnięcia swoich własnych zamierzeń.

Wzrost poziomu innowacyjności związany z preferencją czasową odzwierciedla również dostępność i sposób wykorzystania kapitału. Od niego bowiem zależy wzrost poziomu produktywności pracy, poziom płac realnych oraz szeroko rozumiany poziom życia. Poziom i zakres wykorzystania kapitału determinuje rozwój technologiczny, który z kolei wpływa na wielkość podaży dóbr. Rosnąca podaż pozwala na większą dostępność do dóbr i usług przez podmioty gospodarcze, czyli decyduje o jakości życia. Zależność ta dotyczy również dóbr kapitałowych.

Kluczowym czynnikiem rozwoju technologicznego jest akumulacja kapitału. Aby postęp techniczny mógł nastąpić, teraźniejsze dobra kapitałowe należy wykorzystać do produkcji przyszłych dóbr kapitałowych, przynajmniej w takiej samej ilości. Proces trwałej akumulacji może się opierać na oszczędnościach i wskaźniku kapitał/dochód przy spełnieniu dwóch warunków [Reisman 2015, s. 49]:

1) na produkcję dóbr kapitałowych powinien być poświęcony odpowiedni procent wyprodukowanych dóbr, czyli większy od tego, który jedynie pozwoliłby zastąpić dobra kapitałowe wykorzystane w produkcji; jest to zależne od relacji popytu na dobra kapitałowe w stosunku do popytu na dobra konsumpcyjne, czyli od poziomu oszczędności brutto w stosunku do wydatków konsumpcyjnych;

2) malejące przychody skali, związane z przyrostem dóbr kapitałowych przy takiej samej ilości siły roboczej, muszą być równoważone przez postęp techniczny.

Jest to ściśle związane z utrzymaniem trwałego wzrostu podaży dóbr kapitałowych. Jeżeli dóbr kapitałowych będzie przybywać i będzie postępować akumulacja kapitału, gwarantuje to wzrost ogólnego poziomu życia w sposób nieograniczony i na stałym poziomie.

Reasumując, coraz większe korzyści z postępu technicznego osiągać będą systemy gospodarcze, które charakteryzują się rosnącą wielkością wskaźnika kapitał/dochód. Wskazuje on na większe możliwości wykorzystania oszczędności, czyli korzystniejsze ich zainwestowanie, szczególnie w dłuższe etapy produkcji. Zatem systemy gospodarcze o wyższym poziomie oszczędności i akumulacji kapitału mają większe możliwości korzystania z postępu technicznego. Dzięki większej kapitałochłonności można wprowadzać bardziej skomplikowane i bardziej radykalne rozwiązania technologiczne. 
Postęp techniczny jest ściśle związany z poziomem akumulacji kapitału i tworzy się między tymi kategoriami sprzężenie zwrotne. Aby akumulacja mogła się odbywać, postęp techniczny przenosi malejące przychody skali na inne grupy dóbr kapitałowych, z kolei akumulacja kapitału jest niezbędna do tworzenia nowych rozwiązań technologicznych.

Wielu ekonomistów „głównego nurtu” twierdzi, że technologia produkcji zależy od bieżącego stanu wiedzy technicznej. Ekonomiści austriaccy pokazują, że o wyborze jednej spośród wielu znanych technik produkcji decyduje podaż dóbr kapitałowych dostępnych w danym momencie [Hayek 2009, s. 48]. Według Misesa tym, co hamuje wprowadzanie postępu technicznego (innowacji technicznych), nie jest brak wiedzy technicznej, lecz brak kapitału, który jest niezbędny do przekształcenia przestarzałego aparatu produkcyjnego według nowych, dostępnych w bardziej rozwiniętych krajach rozwiązań. Dogonienie krajów bardziej innowacyjnych musi się rozpocząć od zgromadzenia oszczędności pozwalających na zatrudnienie czynników produkcji w bardziej czasochłonnych procesach wytwarzania. „Dopiero wtedy stałoby się możliwe produkowanie coraz większych ilości narzędzi potrzebnych do budowy zakładów, które następnie wytwarzałyby wyposażenie niezbędne do organizacji, budowy i funkcjonowania nowoczesnych fabryk" [Mises 2007, s. 421].

Niedostatek kapitału może być neutralizowany uzyskiwaniem gotowych dóbr kapitałowych z krajów lepiej rozwiniętych, co pozwala skrócić fazę oszczędności i akumulacji oraz szybciej korzystać z nowych technologii. „Zwiększenie ilości dostępnych dóbr kapitałowych umożliwia osiagnięcie odleglejszych celów bez konieczności ograniczania konsumpcji. Zmniejszenie zaś ich sprawia, że trzeba powstrzymać się od dążenia do pewnych celów, do których można było dążyć wcześniej, lub ograniczyć konsumpcję. Posiadanie dóbr kapitałowych oznacza, że przy pozostałych warunkach niezmiennych zyskuje się na czasie" [Mises 2007, s. 422].

Posiadanie większej ilości kapitału daje przewagę rynkową, dzięki której poszczególni przedsiębiorcy wyprzedzają swoich konkurentów w czasie. Uzyskują i wykorzystują rozwiązania technologiczne znacznie wcześniej, co daje im możliwość osiagnięcia swego rodzaju „renty monopolistycznej”.

Istotą postępu technicznego będzie zatem utrzymywanie zdolności do wzrostu podaży dóbr i usług poprzez dodatkowe zapasy dóbr kapitałowych. Dzięki niemu spadają ceny, ale nie wpływa to w żaden sposób na stope zysku [Reisman 2015, s. 56].

\subsection{Kapital w Schumpeterowskiej teorii innowacji}

Nieco odmienne podejście reprezentuje Schumpeter ${ }^{2}$. Pozwala ono ograniczyć zasięg rozumienia technologii i postępu technicznego do czysto technicznych aspek-

${ }^{2}$ Brak jednoznacznej możliwości zaliczenia Schumpetera do szkoły austriackiej powoduje konieczność stworzenia oddzielnej sekcji. Biorąc pod uwagę jego prace, a także specyficzny sposób narracji, Joseph Schumpeter jest znany po prostu jako „Schumpeter” i tak chyba musi zostać w historii myśli ekonomicznej. 
tów prac $\mathrm{B}+\mathrm{R}$. Według niego postęp techniczny jest więc równoznaczny ze wzrostem globalnej produktywności czynników produkcji, czyli z sytuacja, gdy wzrost produkcji jest większy w stosunku do wzrostu nakładów. Wykorzystując funkcję produkcji, analizuje zmiany procesowe będące egzemplifikacją rozwoju innowacyjnego.

Skutki zmian technicznych ujmowane są endogenicznie. Efektem działalności $\mathrm{B}+\mathrm{R}$ są nowe technologie, których wykorzystanie ma doprowadzić do wzrostu produktywności kapitału i pracy w sektorze dóbr kapitałowych. Zatem podobnie jak u innych Austriaków, głównym czynnikiem pozwalającym utrzymywać proces postępu technicznego jest możliwość akumulacji kapitału.

Innowacje stymulowane są możliwościami technologicznymi, natomiast zmiany produktywności - wzrostem lub spadkiem innowacyjności, czyli czynników podażowych. W skali makroekonomicznej powoduje to rozwój gałęzi, gdy wzrost produktywności kapitału staje się coraz łatwiejszy i mniej kosztowny (ogranicza działanie prawa malejących przychodów). Poza tym nie wyczerpuje się zasób dostępnych technik produkcji stanowiących podstawę wzrostu inwestycji.

W skali mikroekonomicznej podejście podażowe oznacza, że inicjatorem działalności innowacyjnej jest kadra B+R. Poszukuje ona możliwości skomercjalizowania efektów innowacji, co w rzeczywistości ma dwie istotne konsekwencje:

1) przedsiębiorstwa $z$ większym zapleczem $B+R$ mają przewagę nad przedsiębiorstwami cechującymi się niewielkim potencjałem $\mathrm{B}+\mathrm{R}$, gdyż liczniejsza kadra pracowników badawczo-rozwojowych potrafi w większym stopniu wykorzystać do celów ekonomicznych postęp w dziedzinie nauk podstawowych;

2) gdy założy się zbliżony poziom potencjału badawczego, aktywność wynalazczo-innowacyjna będzie większa w tych dziedzinach, w których szybciej rozwija się (w badaniach podstawowych) odpowiednia baza naukowa.

Koncepcja podażowa ogranicza zasięg rozumienia technologii i postępu technicznego do czysto technicznych aspektów prac B+R. Według niej postęp techniczny jest więc równoznaczny ze wzrostem globalnej produktywności czynników produkcji, czyli z sytuacja, gdy wzrost produkcji jest większy w stosunku do wzrostu nakładów czynników produkcji [Fiedor 1986, s. 152-153].

Podejście podażowe zostało wprowadzone przez Schumpetera i kontynuowane w pracach m.in. N. Rosenberga [Rosenberg, Birdzell 1994, s. 43-52]. Przedsiębiorcy oczekujący przyszłych korzyści podejmują ryzyko wprowadzenia innowacji na bazie powstałych inwencji i dokonują niezbędnych inwestycji w działalność innowacyjną. Innowacja przez zmianę struktury rynku daje tymczasową pozycję monopolistyczną i zyski innowatorom. Pojawiają się nowi innowatorzy, co zapewnia dyfuzję postępu technicznego i likwidację uprzywilejowanych przedsiębiorstw poprzez konkurencję.

Oparta na funkcji produkcji Schumpeterowska teoria innowacji nie miała jednak znaczenia analitycznego, a jedynie ogólne. Stała się podstawowym modelem teoretycznym neoklasycznej teorii wzrostu i postępu technicznego, kategorią charaktery- 
zującą poszczególne zmiany w relacji nakładów czynników produkcji i ich wpływu na wielkość produkcji. Jej znaczenie najdobitniej ukazał R. Solow, określając każde przesunięcie funkcji jako przypadek postępu technicznego [Solow 1957, s. 312].

Każda bardziej znacząca innowacja jest ucieleśniona w nowej firmie, która jest konsekwencją zużycia ekonomicznego zasobów kapitałowych. Stopień zużycia decyduje o tempie i zakresie wprowadzania nowych rozwiązań. Działanie tego typu firm nie jest trwałe i w znacznym stopniu zależy od uczestnictwa w procesie innowacyjnym. Innowacje są związane z pojawianiem się nowych osób, których umiejętności pozwalają wprowadzić przedsiębiorstwa na niewykorzystywane dotychczas obszary działalności. W gospodarkach istnieje dość silny opór społeczny przeciwko innowacjom burzącym dotychczasową strukturę społeczno-gospodarczą. Jeżeli powstaje nowa firma, wtedy opór otoczenia jest mniejszy. W strukturze korporacyjnej (oligopol) innowacji dokonują istniejące firmy, a w szczególności kadra menedżerska [Schumpeter 1939, s. 95].

W warunkach wolnej konkurencji skłonność do innowacji słabnie, „tego, co nazywamy postępem gospodarczym, nie da się pogodzić z doskonałą konkurencją. Gdyby większość produktów można było natychmiast naśladować, większość innowatorów straciłaby bodziec do działania" [Schumpeter 1939, s. 85]. Przeszkody utrudniające rozwój wynikają nie z monopolizacji, ale z inercji czy trudności w pokonywaniu ryzyka. Dlatego też w gospodarce „strustyfikowanej” nie są one wcale większe niż w kapitalizmie wolnokonkurencyjnym.

Procesy ekonomiczne można podzielić na trzy odrębne kategorie: procesy ruchu okrężnego, procesy rozwoju oraz procesy zakłócające ten rozwój (cykliczność i zmiany strukturalne). Istotą konkurencji jest działalność innowacyjna, czyli konkurencja między nowościami a poprzednimi produktami (czy procesami). Pojawiają się oferty produktów czy procesów po niższych cenach ze względu na malejące koszty. Cały rynek funkcjonuje dzięki ciągłej rywalizacji innowacyjnej. Innowacja skutkuje pewną formą monopolizacji, jednak monopol ten ma charakter dynamiczny (przejściowy).

Sposób rywalizacji firm prowadzi do zwiększenia znaczenia monopoli, które uzyskują przewagę innowacyjną i stwarzają warunki do dalszego rozwoju technologicznego. Przeczy to tezie o szkodliwości przedsiębiorstw monopolistycznych w tworzeniu innowacji czy wzroście efektywności. Znaczną rolę w tym zakresie Schumpeter przypisuje zarządzaniu innowacjami w warunkach konkurencji.

$\mathrm{W}$ jednych gałęziach następuje rozwój, w innych stagnacja. Zmienia to ład gospodarczy, ale także uruchamia bardzo dynamiczne procesy rozwojowe, które pozwalają osiagnąć ponadprzeciętną stopę wzrostu. Gospodarka odchodzi od stanu równowagi, dążąc do zmiany struktury wynikającej z przewagi innowacyjnej. Rozwój oparty na innowacjach odbywa się w warunkach nierównowagi.

Ważnym punktem Schumpeterowskiej analizy konkurencji opartej na innowacjach jest jej niszczący charakter, prowadzący do bankructwa firm nienadążających za zmianami technologicznymi. 


\section{Wnioski}

Postęp techniczny i kapitał wzajemnie na siebie oddziałują. Akumulacja kapitału wpływa na mechanizm i efekty postępu technicznego i odwrotnie - postęp techniczny determinuje zakres i możliwości akumulacji. Dostępność kapitału i stopień jego wykorzystania mają bezpośredni wpływ na możliwości technologiczne gospodarki, a zatem również na dynamikę rozwoju.

Akumulacja kapitału pozwala na wykorzystanie możliwości technologicznych gospodarki, ale przede wszystkim na przyspieszenie rozwoju opartego na innowacjach. Postęp techniczny wymaga znaczących nakładów kapitałowych, które są efektem oszczędności krajowych podmiotów gospodarczych lub przepływów zagranicznych. Oczywiście druga forma jest uzależniona od wielu elementów endo- i egzogenicznych, które nie zawsze są wystarczające do uruchomienia napływu kapitału. Dlatego też kluczowym czynnikiem jest stworzenie warunków do akumulacji w ramach danej gospodarki. W największym stopniu chodzi o skłonność do oszczędzania oraz wykorzystywania nadwyżek dochodowych przez podmioty gospodarcze.

Kraje wysoko rozwinięte osiagnęły wysoki poziom akumulacji i obecnie mogą realizować rozwój oparty na innowacjach. Jeżeli chodzi o kraje rozwijające się, muszą one, po pierwsze, stworzyć warunki do akumulacji wewnętrznej, a po drugie, pozyskiwać kapitał z zagranicy (pogtębianie kapitału).

Obecnie w wielu gospodarkach dochodzi do erozji kapitału spowodowanej permanentną inflacją oraz rosnącym zadłużeniem prywatnym i publicznym. Transfer kapitału w stronę dóbr konsumpcyjnych trwałego użytku spowodował niedobory w kapitale produkcyjnym. Inflacja wpłynęła na wielkość zysków i ich rosnące opodatkowanie. Procesy te w sposób bezpośredni ograniczyły sektor przemysłowy i zmniejszyły możliwości tworzenia postępu technicznego. Prywatny kapitał produkcyjny został bardzo ograniczony, a środki przejęte przez rządy w znacznym stopniu skonsumowane lub zmarnotrawione. Dodatkowo wiele regulacji ogranicza zakres działalności przedsiębiorstw i podnosi koszty ich funkcjonowania, jeszcze bardziej zmniejszając dostępny kapitał. Konsumpcja z kolei napędzana jest zadłużeniem i nie stanowi rzeczywistego odzwierciedlenia potrzeb produktowych.

Zdynamizowanie procesów innowacyjnych powinno zatem wynikać z przyrostu zasobów kapitałowych, zarówno produkcyjnych, jak i ludzkich. Większa swoboda w dysponowaniu zasobami prywatnymi oraz mniejsze ograniczenia regulacyjne będą pozytywnie wpływać na zmiany technologiczne i tworzyć warunki długookresowego rozwoju gospodarczego.

\section{Literatura}

Arrow J.K., 1962, The economic implications of learning by doing, Review of Economic Studies, vol. 29. Fiedor B., 1986, Neoklasyczna teoria postępu technicznego. Próba systematyzacji i krytycznej analizy, Wydawnictwo Akademia Ekonomiczna, Wrocław. 
Fillieule R., 2005, The , Values-Riches " Model: An alternative to Garrison's Model in Austrian macroeconomics of growth and cycles, The Quarterly Journal of Austrian Economics, vol. 8, no. 2, s. 3-19.

Godłów-Legiędź J., 1992, Doktryna społeczno-ekonomiczna Friedricha von Hayeka, PWN, Warszawa. Grossman G.M., 1996, Economic Growth: Theory and Evidence, E. Elgar Publishing, Brookfield.

Grossman G.M., Helpman E., 1991, Innovation and Growth in The Global Economy, MIT Press, Cambridge.

Hansen G.D., Prescott E.C., 2002, Malthus to Solow, American Economic Review, vol. 92.

Hayek von F., 2003, Droga do zniewolenia, Arcana, Kraków.

Hayek von F., 2009, The Pure Theory of Capital, L. von Mises Institute, Auburn, s. 48.

Hoppe H.H., 2006, Demokracja. Bóg, który zawiódt, Fijor Publishing, Warszawa, s. 33.

Jevons S., 1888, The Theory of Political Economy, Macmillan London, s. 7, www.econlib.org.

Kuznets S., 1930, Secular Movements in Production and Prices, Riverside Press, Boston.

Lucas R., 1988, On the Mechanisms of Economic Development, Journal of Monetary Economics, no. 22.

Mansfield E., 1995, Innovation, Technology and the Economy, Edward Elgar, Aldershot.

Marshall A., 1920, Principles of Economics, MacMillan London, www.econlib.org.

Menger C., 2014, Zasady ekonomii, Fijor Publishing, Warszawa, s. 68-69.

Mises von L., 2007, Ludzkie działanie, IM Warszawa, s. 411.

Nelson R., Phelps E., 1966, Investments in humans, technological diffusion and economic growth, American Economic Review, vol. 61.

Parente S.L., Prescott E.C., 2000, Barriers to Riches, MIT Press, Cambridge.

Phelps E., 1966, Models of technical progress and the golden rule of research, Review of Economic Studies, vol. 33.

Rebelo S., 1991, Long-run policy analysis and long-run growth, Journal of Political Economy, vol. 99.

Reisman G., 2015, Kapitat i kapitalizm XXI wieku, Fijor Publishing, Warszawa, s. 49.

Romer P., 1990, Endogenous technological change, Journal of Political Economy, vol. 98.

Romer P., 1986, Increasing returns and long run growth, Journal of Political Economy, vol. 94.

Rosenberg N., 1982, Inside the Black Box. Technology and Economics, Cambridge University Press.

Rosenberg N., Birdzell L.E., 1994, Historia kapitalizmu, Znak, Kraków.

Rostow W.W., 1960, The Stages of Economic Growth: a Non-Communist Manifesto, Cambridge University Press.

Schmookler J., 1966, Invention and Economic Growth, Harvard University Press.

Schumpeter J.A., 1939, Bussiness Cycles. A Theoretical, Historical and Statistical Analysis of Capitalist Process, vol. 1, Porcupine Press, London.

Silverberg G., Soete L., 1994, The Economics of Growth and Technical Change, Edward Elgar, Brookfield.

Smith A., 1904, An Inquiry into the Nature and Causes of the Wealth of Nations, London Methuen, www.econlib.org.

Solow R., 1967, Some Recent Developments in the Theory of Production, The Theory and Empirical Analysis of Production, McMillan, New York.

Solow R., 1957, Technical change and the aggregate production function, Review of Economics and Statistics, vol. 39.

Tunzelmann von N., 1995, Technology and Industrial Progress, Edward Elgar, Aldershot, s. 20-26.

Uzawa H., 1965, Optimum technical change in an aggregative model of economic growth, International Economic Review, vol. 6.

Ziesemer T., 1993, Endogenous growth with public factors and heterogeneous human capital producers, MERIT, Maastricht. 